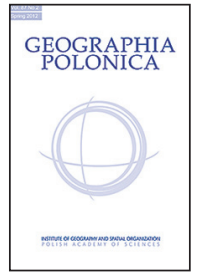

\title{
THE DYNAMICS OF THE TIMBERLINE ECOTONE ON THE ASYMMETRIC RIDGE OF THE BABIA GÓRA MASSIF, WESTERN CARPATHIANS
}

\author{
Barbara Czajka ${ }^{1}$ - Adam Łajczak ${ }^{2}$ - Ryszard J. Kaczka ${ }^{1}$ \\ ${ }^{1}$ Faculty of Earth Sciences \\ University of Silesia in Katowice \\ Będzińska 60, 41-200 Sosnowiec: Poland \\ e-mails: barczajka@wp.pl・ryszard.kaczka@us.edu.pl \\ ${ }^{2}$ Institute of Geography \\ Pedagogical University of Krakow \\ Podchorażych 2, 30-084 Krakow: Poland \\ e-mail: alajczak@o2.pl
}

\begin{abstract}
Timberline ecotone (TE) generally developed because the temperatures in the environment were too low. There are other overlapping biotic and abiotic factors which affect the TE. The main aim of this work was to determine how the asymmetry of Babia Góra's ridge influences the location and characteristics of the timberline ecotone nowadays, and how the ridge influenced the timberline ecotone in the mid-20th century. The asymmetry of environmental conditions means the timberline has formed in two extreme environments: on the sunny and gentle southern slope ( $40 \%$ of the timberline length) and on the cold, humid, steep northern slope (another $40 \%$ of the timberline length). The southern slope of the ridge shows a progressive timberline length of $86 \%$. In turn, $81 \%$ of the timberline on the northern slope is in a stable ecotone.
\end{abstract}

\section{Key words}

Babia Góra Mt. • geomorphometry • ridge asymmetry • timberline shift

\section{Introduction}

Environmental stress refers to the factors limiting and destructing the growth of a species. The intensity of this stress factor causes the biological boundaries. The treeline ecotone is one of the tension zones where the climate becomes too severe for ligneous plant growth (Körner 2003). In the last twelve thousand years, the warmer and colder climate fluctuations, has helped cause the treeline ecotone in the Western Carpathians to change to within a 300 m elevation band (Obidowicz 1996, 2003). Nowadays, a further upward 
shift in the treeline ecotone is expected due to global warming (Kullman 2001). The effects of climate change overlap with the impact of human activity dating back $~ 300$ years (at Babia Góra Mt.) (Obidowicz 2004). The extent of the expected change may be either augmented or reduced due to long-lasting human impact in the alpine environment. Furthermore, the sensitive ecotone of the timberline is controlled not only by the aforementioned temperature and human activity, but also by a range of other environmental factors, widely studied and discussed in research articles on this subject (see Czajka et al. 2015a). The most important additional factors controlling the timberline are: rapid geomorphological processes, soil cover, interspecies competition, air pollution, incident radiation, the size and shape of the mountain range, topography and landforms, and the applied forms of nature conservation (Körner 2012). Alongside varying abiotic factors in the alpine environment, the biotic components change distinctly.

On the Babia Góra massif (Outer Western Carpathians, $1725 \mathrm{~m}$ a.s.I.) the timberline (the lower boundary of the treeline ecotone) has developed with an asymmetric cross-section, which has determined other elements of the environment. The issue of the functioning of the subalpine forest marginal zone has yet to be analysed in relation to the irregularity of the Babia Góra environment. It is assumed that the geomorphological asymmetry of the ridge exerts a significant influence on the location of the timberline. The geomorphological asymmetry of the ridge also has an influence on the possibility and probability of the timberline's upslope advance as well as on the timberline's structure and the condition of the plant communities within the ecotone.

The asymmetry of the Babia Góra ridge has been frequently described in a qualitative fashion, but its geomorphology still lacks a quantitative depiction. This can be achieved using geomorphometry (Pike et al. 2008); a quantitative method of landform characterisation that employs Digital Elevation Models (DEMs) and statistical and mathematical analyses based on the models. These tools have been commonly used during the last decade in the research on landforms in the Sudetes (Kasprzak \& Traczyk 2010), the Carpathians (Długosz 2012; Wężyk et al. 2008), and the Alps (Razak et al. 2011).

The main aim of this work was to determine how the asymmetry of the Babia Góra ridge influences the location and characteristics of the contemporary and historical timberline ecotone. This goal has been achieved by realising the following objectives:

- to identify changes in timberline location on the Babia Góra ridge from 1964/65 to 2009;

- to characterise changes of the timberline ecotone environment in this period,

- to classify the observed changes in the spectrum of 3 types: stable, progressive or regressive boundary.

\section{Study site}

Babia Góra (1725 m a.s.l., 45 km² massif surface area) is the highest peak in the Beskid Żywiecki Mts. of the Outer Western Carpathians (Kondracki 1978). It is also the northernmost Carpathian massif where a timberline has developed. The isolation of the massif and its east-west direction with the ridge bending slightly south (Fig. 1A), determine that the area between the timberline and the main ridge consists of northern and southern slopes which make up $25 \%$ and $59 \%$, respectively. The eastern and western exposures score an $8 \%$ share each (Fig. $1 \mathrm{~B}$ and C). The massif acts like a barrier capturing the incident radiation and precipitation coming into the Orawa-Nowy Targ Basin, which causes the climate of the Babia Góra Mt. to be more oceanic than in other massifs of the Western Carpathians (Zientarski 1985).

The irregularity of the ridge's cross-section influences the other elements of the environment, and this phenomenon has been mentioned by several authors (Zapałowicz 1879; Celiński \& Wojterski 1963; Kasprowicz 1996; Łajczak 1998; Hałat 2006). The ridge is situated with its longer axis directed latitudinally (east-west). The monoclinal arrangement of the 

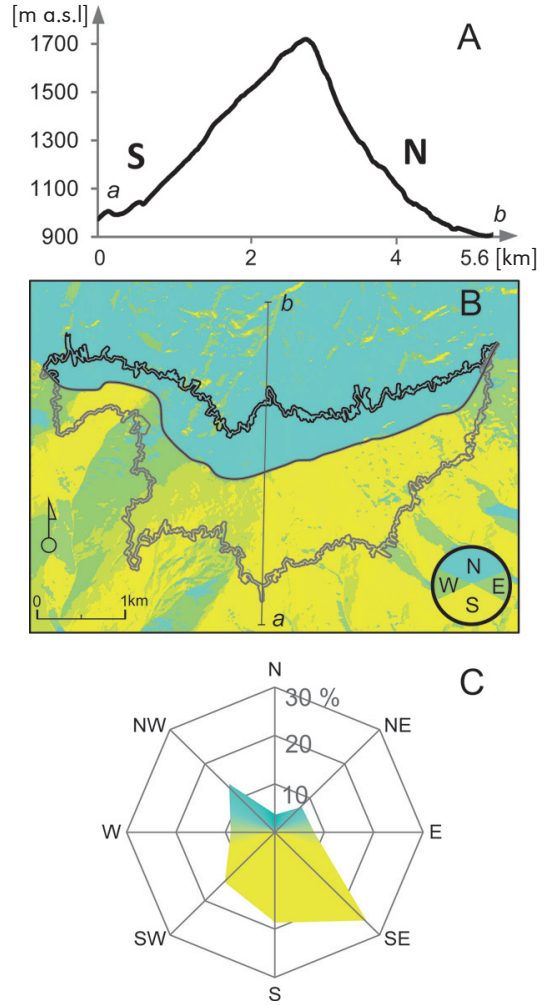

C

Figure 1. The characteristics of the Babia Góra massif

Altitudinal profile (A); slope exposure with a detailed view on the timberline ecotone and the zone above it (B); percentage of particular slope exposure directions in the total area of the massif (C)

upper Eocene Magura sandstone layers, dipping southwards at a small $15-20^{\circ}$ angle, led to the formation of a cuesta (Ksiązikiewicz 1966, 1968). Its southern slope is gentle since it corresponds with the layer dip. The opposite is true for the northern slope's intersecting geological layers (Książkiewicz 1966, 1968; Ziętara 1989). The tectonic asymmetry of the massif is mirrored by the range of other elements of Babia Góra's abiotic environment, such as landforms and mass movements (Łajczak 1998), hydrographic conditions (Łajczak 1999), and slope angle and incident radiation, which all together form the landscape diversity (Hałat 2006).

On the northern slope of Babia Góra Mt., vast areas of primeval subalpine forest remain

(Celiński \& Wojterski 1963). The timberline occurring on the northern slope is a distinct marginal zone of the subalpine vegetation extent and is composed mainly of Norway spruce Picea abies L. Kars, with an admixture of European mountain ash Sorbus aucuparia L. By the 19th century, researchers were already showing an interest in the timberline (see Czajka et al. 2015a). The pasturing in the area, dating a few centuries back, was mainly concentrated on the gentle southern slope (Jostowa 1972). Since the area is divided between two countries, the history of the area's management and environmental protection, has differed. The first attempts at nature conservation on Babia Góra Mt. commenced in the 1920s, in both Poland and Czechoslovakia (nature reserve management-type introduced in several fragments of the spruce forest, including the timberline zone). The national park on the Polish side of the border was created in 1954, while the Slovakian part has only been functioning within the landscape park Chránená krajinná oblast' Horná Orava since 1979 (Omylak 2005).

\section{Methodology}

\section{The asymmetry of the Babia Góra massif}

The quantitative analysis of the asymmetry between the northern and the southern slope of Babia Góra Mt. was conducted according to the assumptions and tools of geomorphometry (Pike et al. 2008). The analysis was based on a division of the ridge into zones. The three following zones are distinguished on the $\mathrm{N}$ and $S$ slopes separately, amounting to six zones all total:

1. the subalpine forest starting from the average elevation of its lower, climatic boundary (1150 m a.s.l. according to Celiński \& Wojterski 1963);

2. the 30-meter-wide ecotone of timberline;

3. the alpine vegetation zones, up to the main ridge of the massif.

The tectonic asymmetry results mainly in the differentiation of landform diversity as well as of the hydrographical and climatic 
conditions. A detailed analysis was possible thanks to the high precision elevation data (horizontal error $X Y_{\text {RMS }}<0.3 \mathrm{~m}$; vertical error $Z_{\text {RMS }}<0.2 \mathrm{~m}$ ) obtained with Airborne Laser Scanning (ALS) at the density of 6 points per square meter, which enabled a detailed characterisation of the forested alpine environment (Næsset 1997; Næsset \& Økland 2002).

The geomorphometric analyses were conducted using both, primary (surface area, slope inclination) and secondary parameters (derived from the transformation of the digital terrain model), such as 3D surface, Topographic Position Index (TPI), Area Solar Radiation and drainage density. The 3D (stereometric) surface of the individual zones in alpine areas may exceed, by even $20 \%$, the 2D surface (corresponding to the slope area projected onto a horizontal surface; Guzik 2008). The differences between the $2 D$ and $3 \mathrm{D}$ surface are directly correspondent to the steepness of the slopes.

The Topographic Position Index parameter describes the diversification of landforms based on a neighbourhood algorithm and the difference between a given pixel altitude and the average altitude of its surrounding pixels (Jenness 2006). Positive values of this parameter refer to convex landforms (peaks, ridges etc.) and zero values describe flat areas, while the negative values show concave areas (river valley bottoms, gorges etc.). The results obtained depend on the given neighbourhood extent: here, a $200 \mathrm{~m}$ area around each pixel was chosen for the generalisation of the relatively large area taken into account (0.5-10 km²).

The most important environmental parameter that models the altitudinal range of forest occurrence, is the temperature (Troll 1973), which significantly changes within the massif (Obrębska-Starklowa 1963). Indirectly, the data on weather diversity may be derived from remote sensing of the incident radiation $\left(\mathrm{KWh} / \mathrm{m}^{2}\right)$. For this purpose, the tool 'Area Solar Radiation' was used. This tool calculates radiation based on the DEM model (containing altitude, latitude, slope angle, exposure, and microtopography). The input parameters for this tool were 32 azimuth divisions and the uniform diffuse radiation model (which assumed the incoming diffuse radiation to be the same from all sky directions).

The hydrogeological properties of each of the six delineated zones were characterised by drainage density $\left(\mathrm{km} / \mathrm{km}^{2}\right)$ obtained from 1:10,000 scale topographic maps (Topographic map 1983).

\section{Multiple time-point aerial photograph interpretation}

The subject of this research was the empirically delineated timberline (Sokołowski 1928), i.e. the line connecting the topmost locations of the dense forest. The empirically delineated timberline is a result of the combined action of both natural factors and human influence. It was assumed here, that a 'forest' is built of coniferous species with a minimal tree height of $8 \mathrm{~m}$ and a crown cover density exceeding $40 \%$, and a minimum area of 10 are (Guzik 2008; Czajka et al. 2015a). Forest patches above the general timberline were connected with the timberline if:

- the distance did not exceed 20 m;

- there were no gorges between;

- Pinus mugo scrubs did not occur between.

During the remote sensing analysis, the tree height and crown-cover in the 1960s was determined based on the shadow length seen on panchromatic historical photographs. The precision of the interpretation is $10-15 \mathrm{~m}$ which based on the aerial photo scale and orthorectification errors. Detailed information of the tree height and crown cover for the recent timberline position was derived from the LiDAR data (accuracy $0.5 \mathrm{~m}$ ).

The delineation of the current and historical timberline extent and the analysis of the observed changes were conducted based on the oldest accessible and contemporary aerial images, in agreement with the air-photo interpretation rules. The oldest panchromatic aerial photos of this region, were taken in 1964 and 1965, for the Polish and Slovakian part of the massif, respectively. The Polish part was pictured on 7 stereographic images taken with 
a Wild Ag 131 camera with a $152.32 \mathrm{~mm}$ focal length; scale of 1:15,000. These analogue photographs were digitalised with a resolution of $1814 \mathrm{dpi}$ (14 micrometers). The aerial photos of the Slovakian part were taken in two series during 1965, using an MRB 21/1818 camera: row fourth and fifth, seven pictures were captured with a focal length of $210.64 \mathrm{~mm}$, while in the row second, three pictures were obtained with a $210.91 \mathrm{~mm}$ focal length. The orthophotomaps were created with $0.25 \mathrm{~m}$ horizontal resolution in GeoTiff format (8 bits) using PCl Geomatica v.10 software. The errors of the process of 'Internal orientation' were between 0.5 to 8 pixels. Aerotriangulation was performed using GCPs (Ground Control Points) derived from recent orthophotomaps (2009 and 2003) with representative spatial distribution. As a result, three orthophotomaps were aerotriangulated (Fig. 2). The orthorectification accuracy was within 5-8 $\mathrm{m}$.

The current ortophotomap was prepared using aerial images from the year 2009, in true colour (RGB) and in the coordinate system PUWG 1992, being a variation of the Gauss-Krüger projection. The pixel size corresponded to $0.25 \mathrm{~m}$ in the field.

The historical aerial photographs covered the entire study area except a $200 \mathrm{~m}$ fragment on the southern slope and the marginal zones of the avalanche paths on the northern slope of the Mała Babia Mt. (1517 m a.s.l.). This meant that the photographs covered an area amounting to $\sim 300 \mathrm{~m}$ or $0.8 \%$ of the timberline length in the massif.
The observed changes in the timberline location were classified according to three types:

- stable timberline (ecotone position change in the period 1964/65-2009 not exceeding $10 \mathrm{~m}$, i.e. the estimated measurement precision);

- progressive timberline (upward ecotone shift);

- regressive timberline (downward ecotone shift).

The timberline should be understood not as a line boundary, but rather as a transition zone. Around the defined line, a 30-meter-wide area was marked out (15 m upwards and downwards from the maximum forest extent). The zone below the timberline characterised the environment of the ecotone in 2009 and 1964, while the other zone reflected the environment above the ecotone in 2009 and 1964. The zones were created as vector layers and subsequently converted to raster datasets using the 'Feature to raster' tool with a $1 \mathrm{~m}$ pixel size. Then, pixel by pixel, they were compared using the 'Combine' tool with elevation, slope inclination, aspect, tree height, and tree crown cover (the latter only for the recent timberline position). This was analysed for a pixel total exceeding 2 million. All GIS analyses were performed using the ESRI software: ArcGIS versions 9.3 and 10.2 .2

If the contribution of a particular changing area to the total surface area affected by changes was below $5 \%$ (which is less than $2 \mathrm{~km}$ ), the particular shift was deemed insignificant and excluded from further discussion.

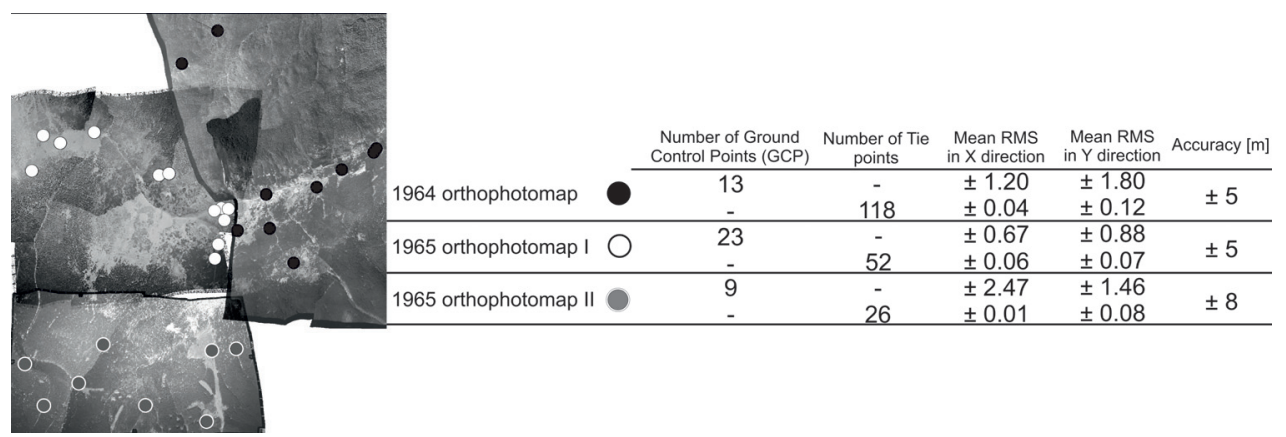

Figure 2. The procedure and parameters of the 1964/1965 aerial images orthorectification 
This rule was applied to the progressive timberline on the northern slopes (NE, N, and NW) as well as to the regressive timberline on the NE, SW, and SE slopes.

\section{Spatial data used in the timberline fluctuation analysis}

The characteristics of the contemporary and historical extent of the timberline in relation to various elements of the environment were undertaken based on the detailed numerical LiDAR (Light Detection and Ranging) dataset. From the point cloud, a raster layer of class 'ground' has been generated, according to the standard classification of LiDAR data (www. asprs.org). A Digital Elevation Model (DEM) and a Digital Surface Model (DSM) were produced in resolution $0.5 \times 0.5 \mathrm{~m}$. The DSM was normalised to nDSM using the DEM, resulting in a raster image where all objects (i.e. trees, buildings etc.) were given heights above ground level. Based on this model, the mean tree height at the timberline ecotone was calculated, alongside the crown cover density of three vegetation classes: $>3 \mathrm{~m}, 3-1 \mathrm{~m}$, and $<1 \mathrm{~m}$. A tree was defined as an individual of the species: Norway spruce, mountain ash or occasionally Swiss pine, of a height exceeding $3 \mathrm{~m}$ (Paulsen et al. 2000). The slope inclination (in degrees) and aspect, were also calculated from the model.

\section{Results}

\section{The asymmetry of the abiotic environment of Babia Góra Mt.}

The asymmetry between the northern and southern slope of the Babia Góra Mt., expressed by the extent of three altitudinal vegetation and climate zones (Fig. 3A), is distinct but diversified, which is confirmed by quantitative parameters (Fig. 3B). The surface area of all zones on the northern slope is less than for the respective areas of the southern slope (between 140\% and 300\% less). The closest match between slopes was found between areas of the timberline ecotone on both slopes (the southern ecotone occupying a 40\% larger area). On the other hand, the difference between the 2D and 3D surface areas were highest on the northern slope, of up to $16 \%$. This was twice as much as the highest difference found on the southern slopes. The most dissimilar were the zones above the timberline. On the southern slope, the zone above the timberline was characterised by the lowest slope angle $\left(16^{\circ}\right)$ and relatively uniform morphology $\left(\sigma^{2} \mathrm{TPI}=757\right)$, at the same time receiving the highest incident radiation during the vegetation season $\left(987 \mathrm{KWh} / \mathrm{m}^{2}\right)$. The same vegetation and climate zone on the northern slope showed moderate slope angles $\left(29^{\circ}\right)$, much higher landform diversity $\left(\sigma^{2} \mathrm{TPI}=1753\right)$, and very small incident radiation doses $\left(693 \mathrm{KWh} / \mathrm{m}^{2}\right)$. The subalpine forest zones had the smallest differences between the two slopes: in incident radiation $\left(183 \mathrm{KWh} / \mathrm{m}^{2}\right)$, slope inclination $\left(3^{\circ}\right)$, 3D surface $(3 \%)$, and drainage density $\left(0.5 \mathrm{~km} / \mathrm{km}^{2}\right)$, and also in landform diversity $(\sigma 2 \mathrm{TPI}=263)$. The focus of the analysis was the environment of the timberline ecotone. This environment showed a much stronger asymmetry than the entire subalpine forest zone, resembling more the alpine zone in this respect. The incident radiation had a $40 \%$ smaller intensity on the northern slope. The slope angle was, on average, $10^{\circ}$ steeper, and the lanforms were more diversified ( $\sigma^{2}$ TPI being 1.8 times larger than on the southern slopes), while drainage density was 2 times lower on the northern slope.

\section{The contemporary and historical location of the timberline}

The timberline on Babia Góra Mt. currently extends for $\sim 38 \mathrm{~km}$. This length has only slightly changed within the last 45 years $(1 \%)$ (Fig. 4A). In 2009, the upper timberline was located at the mean altitude of $1370 \mathrm{~m}$ a.s.l., which is a $16 \mathrm{~m}$ upslope shift if compared to the 1964 location (Fig. 4B). Currently, the minimal altitude is achieved by the timberline in the avalanche path on the northern slope beneath the Mała Babia peak (1106 m a.s.I.). The dense forest reaches the highest elevation at $1508 \mathrm{~m}$ a.s.l. in Slovakia, in the area called 


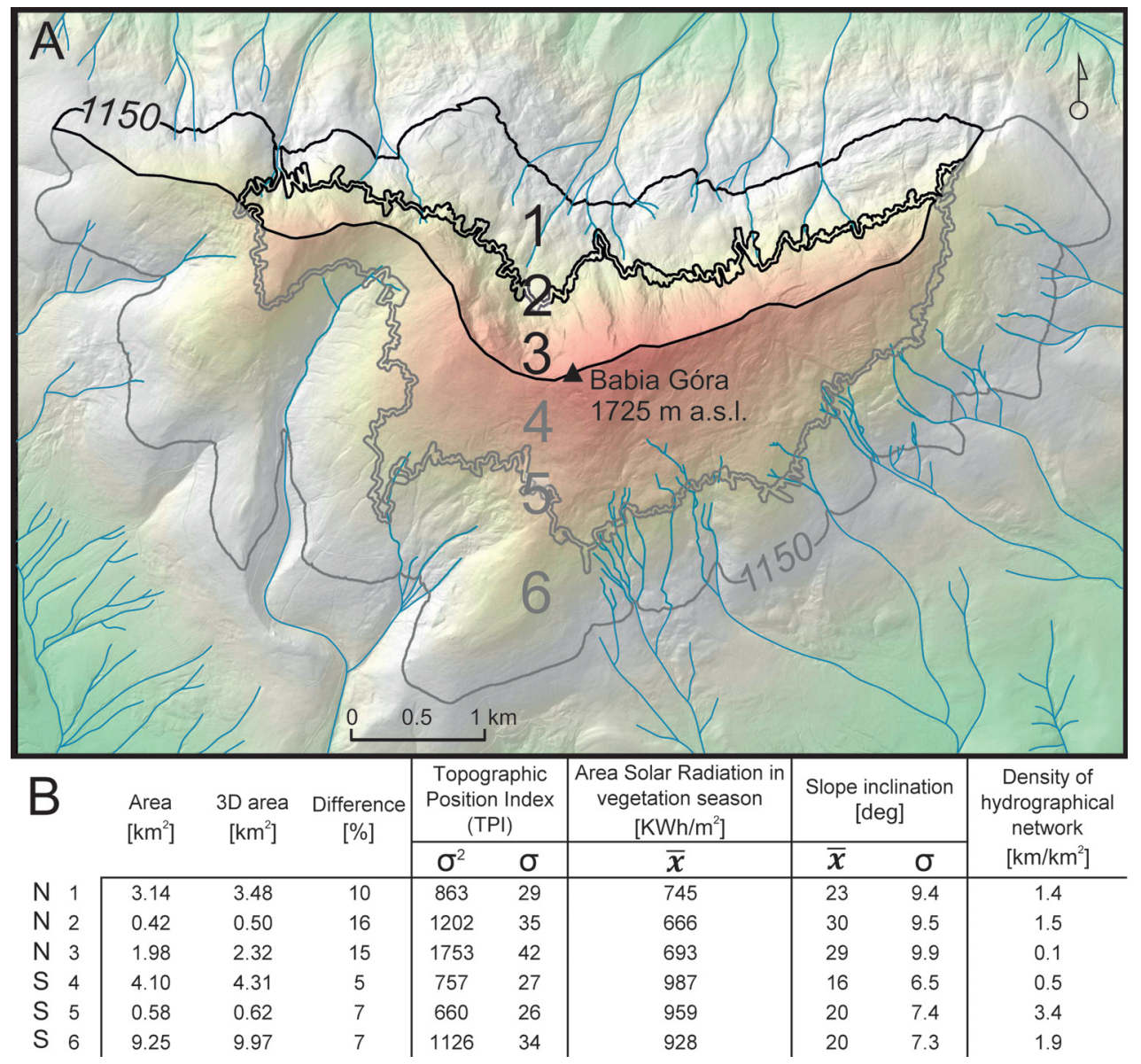

Figure 3. The locations of the six vegetation and climate zones (A) delineated for the quantitative analysis of the environment asymmetry on the Babia Góra ridge (B): the subalpine forest altitudinal zone $(1,6)$; timberline ecotone $(2,5)$; and the alpine zone $(3,4)$

Rabčická hola. In the 1960s, the lowest extent of the forest occurred in the same avalanche path (1106 $\mathrm{m}$ a.s.l.) and additionally at the southern slopes at Slovakian part of the massif near the country border it was just as low at 1108 m a.s.l. In the 1960s, the maximum height at which dense forest occurred was $1464 \mathrm{~m}$ a.s.l., and the timberline fragments at this altitude were found in the Slovak part of the Mała Babia Mt. Despite those changes, the mean slope angle of the timberline ecotone has not changed and amounts to $24^{\circ}$.

The classification of the timberline according to the changes taking place, has shown that $61 \%$ of the timberline in the studied period was stable, while $32 \%$ and $7 \%$ were progressive or regressive, respectively (Fig. 5B). At present, the highest mean and maximum altitudes are reached by the subalpine forest in the progressive stretches of timberline (and these are 1407 and $1508 \mathrm{~m}$ a.s.l., respectively). The timberline that was stable during the study period was found mostly in the Polish part of the massif (Fig. 5A). Moreover, the slope angles under the timberline have changed alongside the altitudinal shift, with a pattern of the timberline lowering on the steepest slopes $\left(32^{\circ}\right)$ and the timberline 


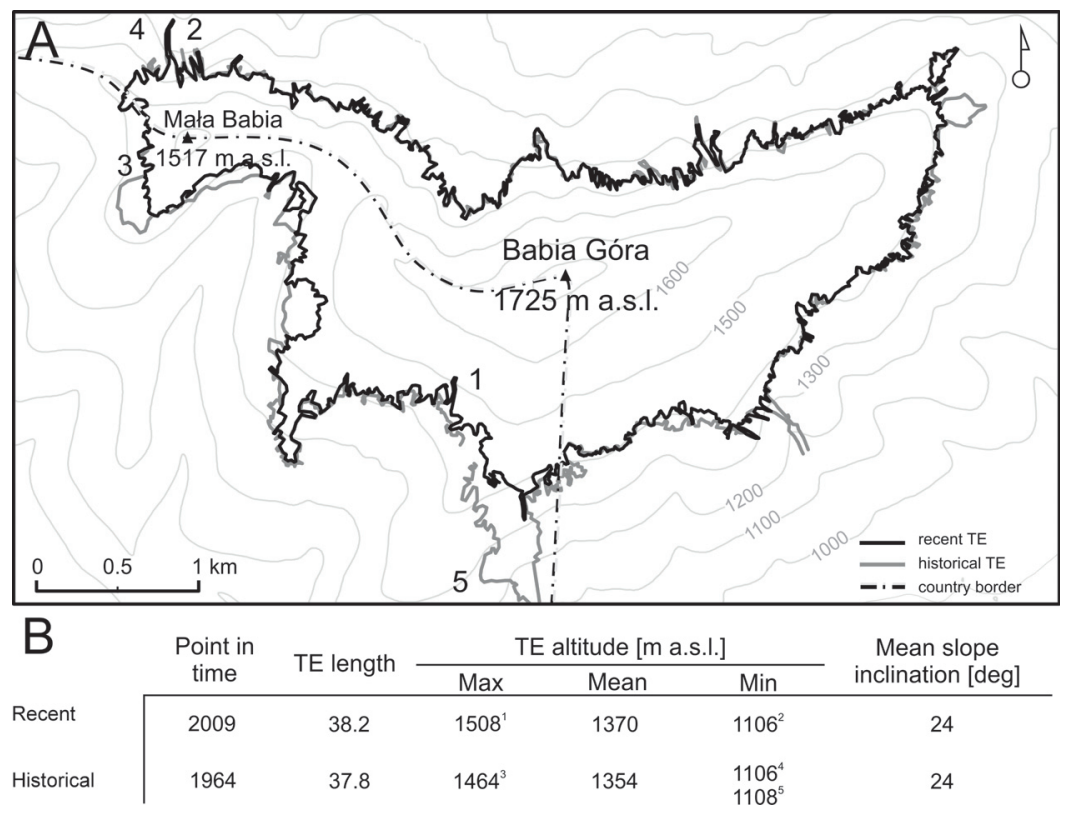

Figure 4. Changes in the timberline on the Babia Góra massif between 1964 and 2009 (A) and the basic parameters of the timberline (B)

${ }^{1-5}$ the maximum and minimum forest extents at the studied time points

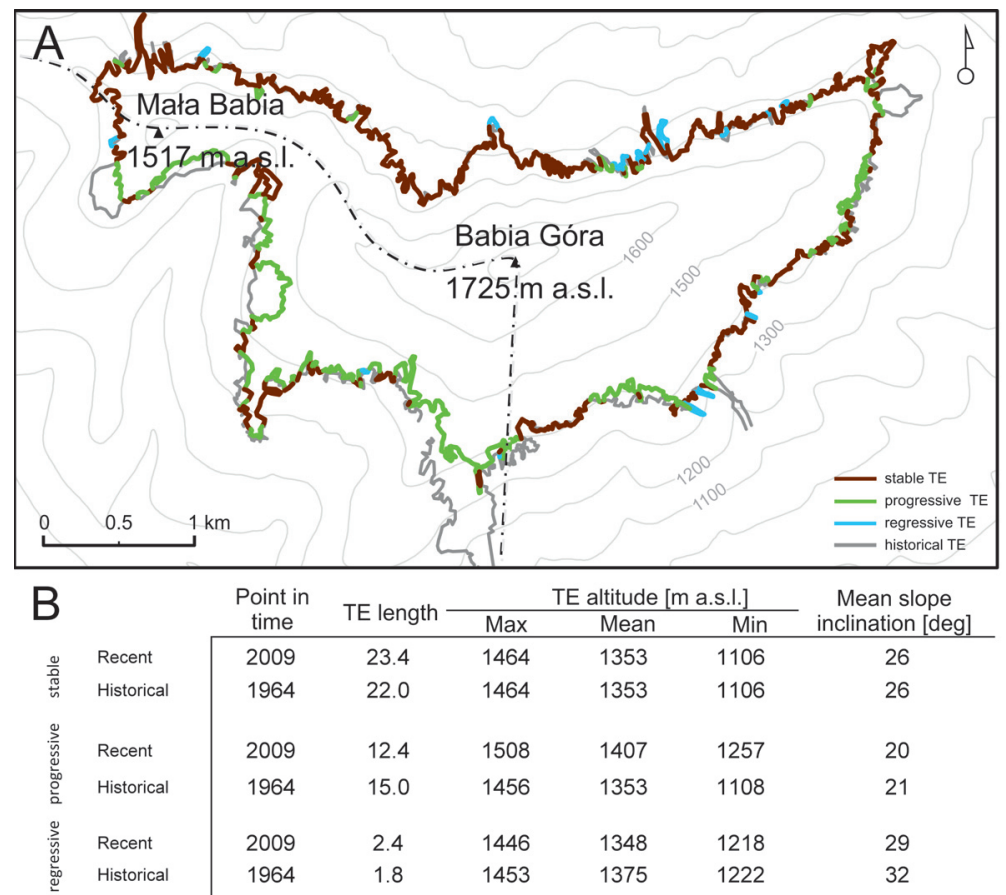

Figure 5. The location (A) and basic parameters (B) of the timberline changes on the Babia Góra Mt. 
progressing on the gentlest slopes $\left(21^{\circ}\right)$. The stable timberline was located mostly on slopes with a moderate inclination $\left(26^{\circ}\right)$.

\section{The asymmetry of the contemporary and historical timberline ecotone}

Both the contemporary and the historical position of the timberline have been functioning in heterogenic environmental conditions, depending on the location within the massif. The same $41 \%$ share of the timberline length was located on both the northern slopes (NE, $N W$, and $N$ exposures) and the southern ones (SE, SW, and S exposure). The remaining 18\% was divided on the eastern and western slopes in equal proportions (Fig. 6A). In the period from 1964 to 2009, the timberline had increased in length on the N and NW slopes, and decreased on the SW and S slopes. However, these differences were at the level of $3 \%$ $(\sim 1 \mathrm{~km})$. The timberline reached the lowest mean altitude on the northern slope of the massif (1335 $\mathrm{m}$ a.s.l.) and the highest altitude on the western slopes (1412 $\mathrm{m}$ a.s.I.). On the northern slope, the mean timberline altitude

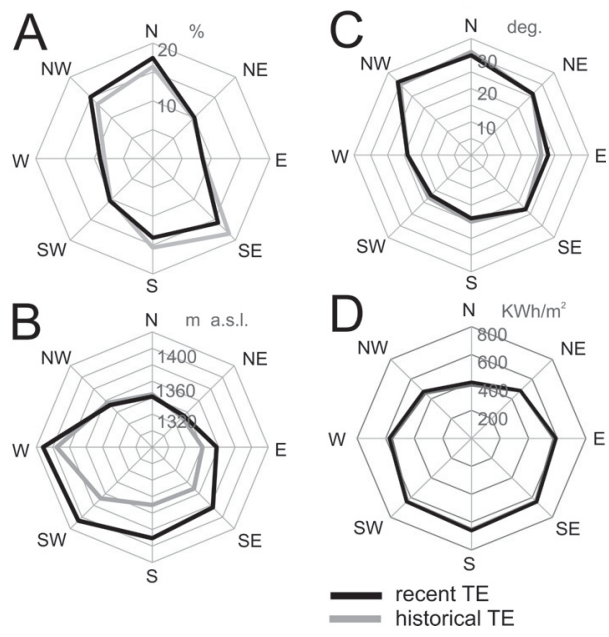

Figure 6. Characteristics of the recent and historical timberline on Babia Góra Mt. in relation to slope aspect. Timberline location: A - length; B - average altitude; C - mean slope angle; $D$ - mean incident radiation has not changed during the last 45 years. In the other parts of the massif, the timberline position markedly progressed: by $10 \mathrm{~m}$ in elevation on the eastern and western slopes and by as much as $30 \mathrm{~m}$ (to $1395 \mathrm{~m}$ a.s.l.) on the southerly exposed slopes (SW, SE, and S). The maximum change reached $40 \mathrm{~m}$ at the $S$ exposure (Fig. 6B). The timberline is now associated with the steepest slopes in the NW and $\mathrm{N}$ exposure areas (the mean slope angle: $31^{\circ}$ ). The most gentle slopes are crossed by timberline on the slopes of SW exposure (at $17^{\circ}$ ); these features have not changed since 1964 (Fig. 6C). To the timberline ecotone surface, on the N and NW slopes, 380-440 kWh/ $\mathrm{m}^{2}$ incident radiation is supplied during the vegetation period. This is 1.4 times less than on the $E$ and $W$ slopes $\left(550-560 \mathrm{kWh} / \mathrm{m}^{2}\right)$ and almost 2 times less than on the $S$ slopes (640$660 \mathrm{kWh} / \mathrm{m}^{2}$ ) (Fig. 6D).

The observed changes were closely connected with the location of timberline within the massif (Fig. 7). The ecotone surface area (82\%), where the timberline was progressive is located on the southern and western slopes (SE, S, SW, and W exposure), i.e. in the Slovakian part of the massif. The surface area of this ecotone has diminished (the course of the timberline has simplified) on the SE slopes, while increasing on the SW slopes (Fig. 7A-I). There was a 54\% observed timberline lowering which occurred on the northern slope of the massif ( $\mathrm{N}$ and NE exposure). The further $28 \%$ of timberline lowerings were located on the south-eastern and eastern slopes (Fig. 7B-I). The stable timberline was evenly distributed around the massif: the northern and southern slopes noted $55 \%$ and $45 \%$ of stable timberline occurrence, respectively (Fig. 7C-I). The timberline on the northern slope of the massif has a length of $16 \mathrm{~km}$, $81 \%$ of which is a timberline that was stable over the last 45 years.

The average altitude of the progressive timberline is currently at $1400 \mathrm{~m}$ a.s.l. The average changes in the timberline altitude were within the range of $30-80 \mathrm{~m}$, with a minimum on the $W$ slopes and a maximum on the $E$ slopes (Fig. 7A-II). The regressive 

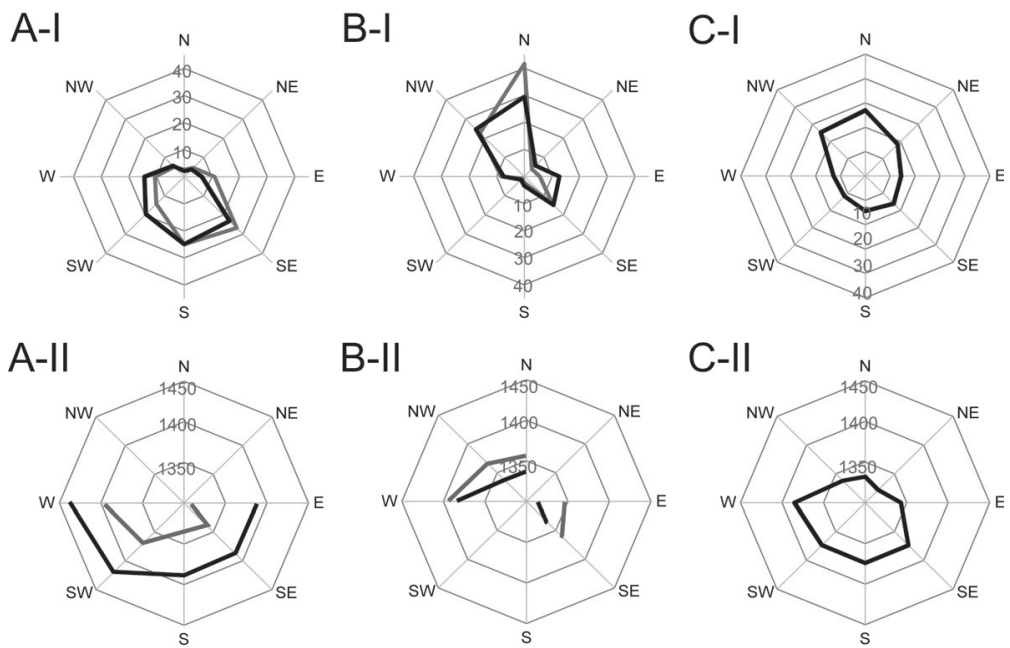

B-II
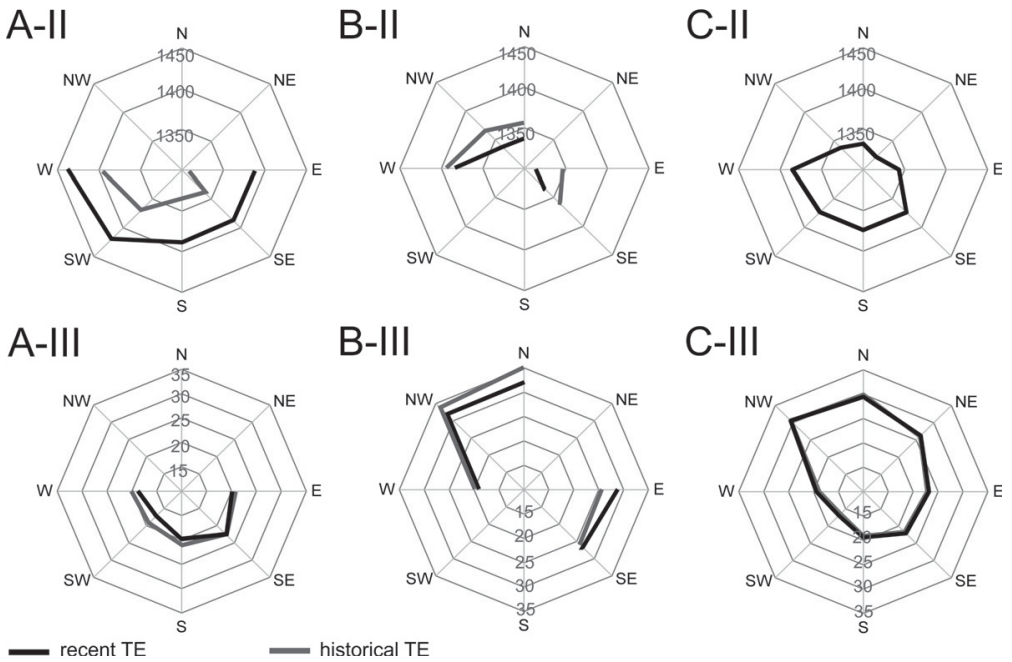

Figure 7. Characteristics of the timberline changes on the Babia Góra Mt. in relation to slope aspect The zones of timberline progression (A), regression (B) and stability (C). The shares of: the area occupied (I), mean altitudes (II), and slope angles (III)

timberline was characterised by the lowest mean altitude; at the level of $1340 \mathrm{~m}$ a.s.l. (Fig 7B-II). The regressive changes were much less than the progressive ones, not only in respect to area, but also in respect to altitude (15-30 m). These changes are not significantly different depending on the slope exposure, and the highest $(30 \mathrm{~m})$ were observed on the eastern slopes.

The mean altitude of the stable timberline is $1350 \mathrm{~m}$ a.s.l. The stable timberline on the northern slopes, where it contributed the highest share in the classification, reaches the lowest mean altitude at 1333 m a.s.l. Stable timberline at the southern slope reached $1374 \mathrm{~m}$ a.s.l. It is located approximately $20 \mathrm{~m}$ lower on the southern slopes than the fragments of progressive timberline on the same slope (Fig. 7C-II).
On the steepest northern slope, the subalpine forest has the lowest altitudinal extent (Fig 7B and C II-III). On the other hand, the south-western, southern, and western slopes exhibit the most gentle slope angles; $18-20^{\circ}$ (Fig. $7 \mathrm{III}$ ), and this is also where the timberline reaches the highest altitudes.

\section{The asymmetry of land covers within the contemporary ecotone of the timberline}

Between $46 \%$ and $74 \%$ of the timberline surface area is composed of vegetation above $3 \mathrm{~m}$ in height. The lowest crown cover density occurred in the progressive timberline class on the W and SW slopes. The highest crown cover density was noted within the stable timberline zone on the NW and E slopes (Fig. 8A-I). The highest share of vegetation $>3 \mathrm{~m}$ in the 
timberline area was found along the timberline that was stable in the study period $(72 \%$ of the surface area). Along this timberline type, independent of location, $10 \%$ of the land was covered with vegetation which was $1-3 \mathrm{~m}$ in height (mainly spruce saplings, but also dwarf mountain pines) (Fig. 8A-II). This vegetation of medium height covered slightly more surface area of the progressive timberline ecotone, especially on the W and SW slopes, where it was mostly spruce saplings (a dwarf mountain pine share was approximately $1 \%$ ). The densest forest occurred on the NW and SE slopes, independent of the timberline character. The mean area of gaps in the crown cover occupied $26 \%$ of the timberline ecotone at the Babia Góra there (Fig. 8A-III). The gaps occurred most frequently on the west-facing slopes, and are classified as progressive timberline ( $40 \%$ land surface area).

The vegetation above the timberline was the reverse of the ecotone, if plant height classes are taken into account. Low grass vegetation and herb communities $(<1 \mathrm{~m})$ covered $60 \%$ of this area (Fig. $8 \mathrm{~B}-\mathrm{III}$ ). In the area of the stable or regressive timberline on the NW and $\mathrm{W}$ slope, the participation of these plant communities decreased (40\%) since plant communities were partly replaced by trees which were $3 \mathrm{~m}$ in height (30-40\%) (Fig. 8B-I). On average, $20 \%$ of the zone above the timberline was covered with vegetation of 1-3 m in height. This vegetation the zone above the timberline (except the S and SW slopes) was made up of a shrub community with dwarf mountain pine (Pinus mugo) dominating, and locally dominated by Juniperus communis $L$. (Fig. 8B-II).

\section{Discussion}

The multi-temporal aerial image interpretation has been widely and successfully used for 150 years as a source of information about environmental changes. Photo interpretation and remote sensing have been used in studies on the dynamics of: geomorphological processes (Westen \& Getahun 2003), plant community succession, the changes in land use and land cover (Fensham \& Fairfax 2002;
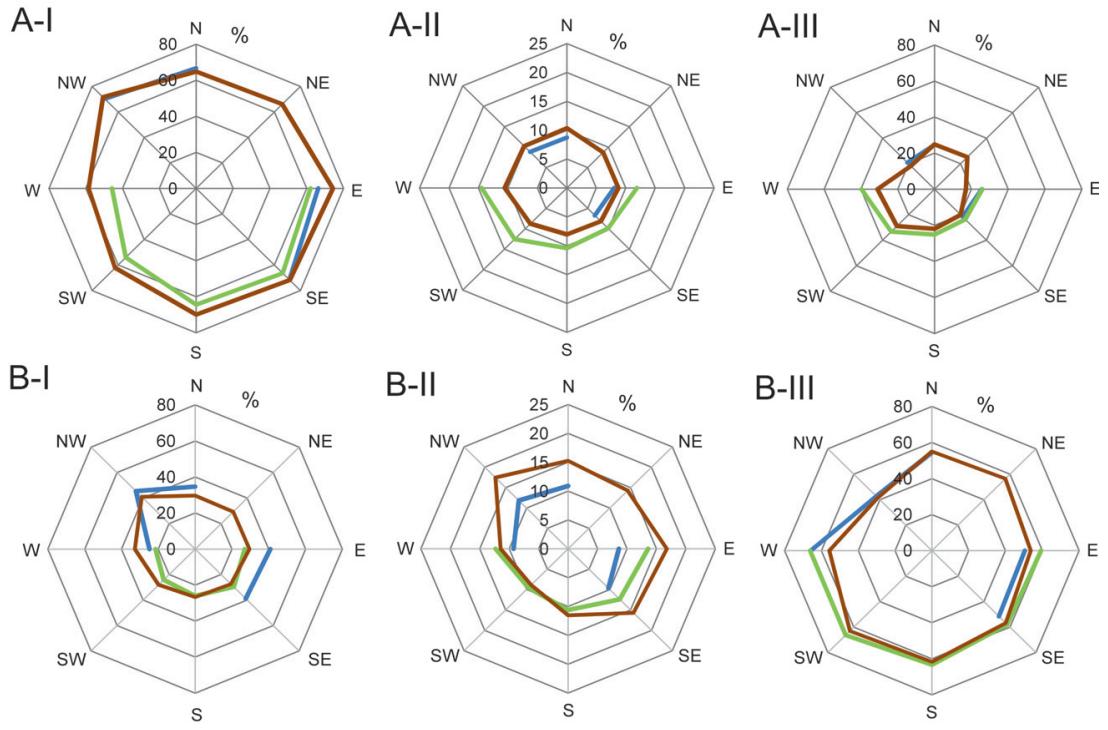

stable TE $=$ progressive TE $=$ regressive TE

Figure 8. The characteristics of the land cover in the area of the timberline ecotone (A) and the zone above it (B) in relation to slope aspect. Vegetation classes: high >3 m (I); medium 1-3 m (II), and low <1 m (III) 
Strand et al. 2006), and in studies on the dynamics of the changes in timberline ecotone (Luo \& Doi 2013). Information from aerial and satellite images was also used in the research on the timberline in the Carpathians by Plesník (1971), and in the Sudetes by Treml \& Banaš (2000) and Treml (2007), and in the Tatra Mts. by Guzik (2008), to analyse spatial changes within the ecotone of the timberline. The use of novel materials (high resolution aerial images, and high precision LiDAR elevation data) and techniques (spatial analyses using DEMs and geomorphometry tools) significantly expand the knowledge about the functioning of the alpine environment (Guzik 2008; Kasprzak \& Traczyk 2010), especially the timberline on Babia Góra Mt. The high precision of ALS measurements, combined with the interpretation of the aerial photographs from multiple points in time, enabled a $10 \mathrm{~m}$ analysis precision to be achieved. The analyses of land cover changes on large territories have been possible since the 1980s, thanks to satellite images from LANDSAT. Such analyses were conducted for the entire Carpathians (Griffits et al. 2014), as well as for the individual mountain ranges of the Carpathians (e.g. Mihai et al. 2007). However, all these studies were regional coverage, and medium-scale resolution. A similar accuracy is found in the comparative studies of the land use on historical and contemporary maps of this area (Kucharzyk \& Augustyn 2008; Sitko \& Troll 2008; Kricsfalusy et al. 2008; Weisberg et al. 2013).

Babia Góra (1725 m a.s.l.) is the second highest mountain massif in Poland (the highest being the Tatra Mountains). In places other than the study area, the timberline in Poland may be observed: in the Tatra Mountains (the range peaking on Gerlach at $2655 \mathrm{~m}$ a.s.l. and occupying an area of $\sim 785 \mathrm{~km}^{2}$ ), in Karkonosze (with the highest peak being Śnieżka; 1602 m a.s.l. and $\sim 650 \mathrm{~km}^{2}$ total area), on Pilsko Mt. (1557 m a.s.l., $15 \mathrm{~km}^{2}$ ), and the Śnieżnik Massif (Śnieżnik 1425 m a.s.l., $5 \mathrm{~km}^{2}$ ), as well as in the Western Bieszczady Mts. (Tarnica $1346 \mathrm{~m}$ a.s.l., surface area $290 \mathrm{~km}^{2}$ ). At present, the empirical timberline on Babia Góra Mt. is one of the shortest timberlines (only exceeding the length of the respective line on Pilsko and the Śnieżnik massifs). The mean altitudinal location at $1370 \mathrm{~m}$ a.s.l., though, is only inferior to the one in the Tatra Mountains (being located 60 m lower) (Guzik 2008). The Babia Góra timberline is located higher than in other massifs, on average, the Babia Góra timberline is: $10 \mathrm{~m}$ higher than the timberline on Pilsko Mt. (Czajka et al. 2015b), $65 \mathrm{~m}$ above the timberline in the Śnieżnik massif (Treml \& Banaš 2000), 140 m higher than in Karkonosze (Treml \& Banaš 2000), and as much as $255 \mathrm{~m}$ above the timberline in the Western Bieszczady Mts. (Zarzycki 1963; Zientarski 1985; Kucharzyk \& Augustyn 2008). However, in this kind of comparison, a significant problem is the different methodology applied by the cited authors. One of the most important differences is the tree height criterion. In timberlines with trees higher than $8 \mathrm{~m}$, the timberlines occur relatively lower and are more stable than timberlines built with trees higher than 3 m (Harsch et al. 2009; Holtmeier 2009).

The differences in the location of the empirical timberline on Babia Góra Mt. have yet to be studied. The cartographic resources from the 19th and the beginning of the 20th century only showed the approximate position of this ecotone (Kozak 2003). The archive forestry maps likewise showed only the approximate position of this ecotone (Celiński \& Wojterski 1962), and the Austrian cadaster also showed the same. The detailed reconstruction of the historical timberline is possible only with the use of archived aerial photographs, and the oldest photos were taken in the 1960s. For the last half-century, $61 \%$ of the timberline extent on Babia Góra Mt. has remained in the same location which is a rare occurrence in the studies on forest extents in the Carpathians and the Sudetes. In the Tatra Mountains, since the 1950s, approximately only 30\% of the timberline length has not changed location (Guzik 2008). Similarly, marked changes have been noted since the beginning of 20th century in the Sudetes (Treml 2007) and in the Western Chornohora Mts. (Sitko \& Troll 2008). However, in 50\% of the studied 
timberline cases worldwide, such changes were not observed (Harsch et al. 2009). The timberline ecotone response to the globally changing environmental conditions is dependent on local circumstances. A strong influence is exerted by the topography and landforms, which have an impact on the spatial structure and physiognomy of the timberline (Holtmeier 2009). The asymmetric morphology of the Babia Góra ridge leads to the development of diverse types of timberline. Microclimates along the massifs diversify the biological and ecological processes. These processes are a result of different exposure (Holtmeier 2009). The asymmetry of Babia Góra ridge has the strongest impact on the position and condition of the subalpine forest. The asymmetry regulates the incident radiation supply and the slope angle also has an indirect effect on timberline dynamic.

At present, the difference between the timberline position on the northern and southern slope of Babia Góra Mt. is, on average, $60 \mathrm{~m}$ a.s.l. The heat deficit is the most important stress factor in the mountainous environment, especially in the mountains of mid-latitude. The heat deficit causes the occurrence of all the most important environmental boundaries (Troll 1973; Tranquillini 1979; Williams et al. 1996). The dendroclimatological research on spruce trees from the timberline ecotone confirms the above assumptions (Aniol \& Eckstein 1984). In the Western Carpathians and Babia Góra Mt., the summer (June-July) temperature and the temperature of the whole vegetation season (April-September) has the highest influence on the spruce tree condition (Bednarz et al. 1999; Büntgen et al. 2007; Czajka 2012; Kaczka et al. 2015). During the vegetation period, lasting from April to September, the timberline ecotone on the northern slope of Babia Góra Mt. is supplied with $40 \%$ less solar energy than the timberline on the southern slope. The higher incident radiation dose accelerates the melting of the snow and results in a prolonged and warmer vegetation period. Solar energy also increases the minimal temperatures in the winter period (Wieser \& Tausz 2007; Holtmeier 2009).
The northern slope angle in the timberline zone of Babia Góra Mt. is, on average, $10^{\circ}$ higher than on the southern slope. The northern slope is also characterised by a higher diversity of landforms. The terrain morphology is one of the most important factors modifying the extent of the timberline on the local scale (Parzóch et al. 2008; Migoń \& Parzóch 2008; Körner 2012). Due to the overland flow and water infiltration, the substratum on the convex landforms contains less moisture than on the sloping surfaces and the adjacent concave microforms (Cairns \& Fonda 1974; Wooldridge et al. 1996). The steepness of the slopes itself does not exert any negative influence on the forest location. The steepness does regulate the occurrence of high-energy mass movements (Holtmeier 2009) such as debris flows, rockfalls or snow avalanches. Also, the erosion leading to the formation of small chutes, gullies, and talus cones has formed a very segmented and diverse course of the timberline on the northern slope of Babia Góra Mt. The timberline on the northern slope is located much lower than on the gentle and relatively uniform southern slope.

During the last half-century, the difference between the timberline position on the northern and southern slopes of the massif has increased by a factor of two. The strongest changes were observed on the western slopes. However, in other massifs the relation between the slope exposure and forest succession to higher elevations, is not necessarily observed (Ciurzycki 2004; Kucharzyk \& Augustyn 2008). Invisible influence of exposure is connected with marked impact of human activity on the environment. The semi-natural sub-alpine forest and its timberline on the northern slope of Babia Góra Mt. is emphasised by several authors (Szwagrzyk et al. 1995, 1996; Holeksa 1998; Vorčák \& Jankovič 2009). The asymmetric slope angles indirectly differentiate the intensity of land use by people since it physically restricts access to some areas. The top sections of the northern slopes have been almost inaccessible for pasturing and forestry. Hence, the more gentle southern slopes were used for these purposes, in some 
places even until the 1970s. The history of land use on Babia Góra Mt. has resulted in the current intensive regeneration and the observed upslope shift of timberline on higher altitudes on southern slopes, and the generally stable and semi-natural timberline forest on the northern slope.

However, these are times of global climate warming, and it is expected that all geosystems will undergo a shift following a warming of $2.5^{\circ} \mathrm{C}(2040-2070)$ (IPCC 2013). Despite the fact that climate warming has been happening for at least 50 years now, for the complex ecosystems, the shift is more of a near future prognosis than an already experienced phenomenon (Körner 2012). The predictions suggest that the upward advance of the ecotone will be strongly constrained by the geomorphological and geological processes, the significance of which will increase further. The expected progression will be heterogeneous and will concentrate on the gentle slopes of south-western exposure with a thick soil cover (Macias-Fauria \& Johnson 2013).

\section{Conclusions}

1. The asymmetry of environmental conditions on the Babia Góra Mt. encompasses the entire massif. It is most pronounced on the NW and SE slopes, but the southern slopes occupy a 3.5 times larger area than the northern slopes. The asymmetry is primarily in the zone of alpine vegetation, as well as within the timberline ecotone. The solar radiation supply to the timberline is $40 \%$ lower on the northern slope, which is $10^{\circ}$ steeper and has more diverse land surface morphology, expressed by a $\sigma^{2}$ TPI that is higher by a factor of 1.8 than on the southern slope.

2. The asymmetry of environmental conditions means that the timberline forms in two very different environments: on the sunny, gentle, and less active in a geomorphological point of view southern slope (40\% of timberline length), and on the cold, humid, and steep northern slope (another $40 \%$ of timberline length). Contemporarily, the timberline on the Babia Góra Mt. has a mean altitude of $1370 \mathrm{~m}$ a.s.I. The timberline is located much higher on the southern slope (1396 $\mathrm{m}$ a.s.I.) than on the northern one (1335 $\mathrm{m}$ a.s.l.)

3. In the period from 1964 to 2009 , the timberline ecotone length on the Babia Góra Mt. has not changed but the altitudinal location has markedly changed. The timberline has shifted upslope by an average of $16 \mathrm{~m}$ in altitude across the massif. In some areas, the timberline shifted by as much as $40 \mathrm{~m}$ (on $\mathrm{S}$ slope). The maximum upslope timberline migration reached to $200 \mathrm{~m}$ in distance.

4. The comparison of the contemporary (2009) and historical (1964) timberline extent shows that the majority of the length of the timberline remained stable (61\%). Only $32 \%$ of timberline length has shown progression, while another $7 \%$ has regressed. The changes in the timberline position on the Babia Góra Mt. are characterised by a marked diversity within the massif. The timberline on the northern slope is $81 \%$ in a stable ecotone, with a small share of both regressive and progressive timberline $10 \%$ and $9 \%$, respectively). On the southern slope of the massif, the contributions of the stable and progressive timberline were equal. On the southern slope of the massif is where $86 \%$ of the progressive timberline length is located.

5. The geomorphological diversification of the massif had an impact on its history, and the intensity of the spatial differences in the land use of the massif. The intensive pasturing which lasted until the 1970s on the southern slopes, has been recently abandoned. This act has led to the regeneration of the forest, and hence, the upslope shift of the timberline in higher altitudes. The inaccessible and unstable northern slopes have indirectly protected the subalpine forest and the timberline from human activity in the area.

6. The land cover structure was diversified within and above the ecotone, depending on the location of the timberline. The 
progressive ecotone had the smallest tree crown cover for individual trees $>3 \mathrm{~m}$ $(56 \% \pm 10 \%)$, but also numerous young trees $(12 \% \pm 2 \%$ for individuals of $1-3 \mathrm{~m}$ in height). On the other hand, the zone above it exhibited a higher proportion of medium vegetation (1-3 m; $12 \% \pm 2 \%$ ), although these were not the plant communities of dwarf mountain pine Pinus mugo, typical for this massif. The limited occurrence of the dwarf mountain pine distinguishes the progressive zone above the timberline from the stable ecotone. In the ecotone, the proportion of medium vegetation was similar, but the composition was dominated by dwarf mountain pine shrubs.

\section{References}

ANIOL R.W., ECKSTEIN D., 1984. Dendroclimatological studies at the northern timberline [in:] W. Karlén, N.A. Mörner (eds.), Climatic changes on a yearly to millennial basis, Dordrecht: D. Reidel, pp. 273-279.

Bednarz Z., Jaroszewicz B., Ptak J., Szwagrzyk J., 1999. Dendrochronology of Norway Spruce (Picea Abies (L. Karst) in the Babia Gora National Park, Poland. Dendrochronologia, 16, pp. 45-55.

Büntgen U., Frank C.D., Kaczka R.J., Versteg A., ZWIJACZ-KOZICA T., ESPER J., 2007. Growth responses to climate in a multi-species tree-ring network in the Western Carpathian Tatra Mountians, Poland and Slovakia. Tree Physiology, vol. 27, no. 5, pp. 689-702.

CaIRns B.B., Fonda R.W., 1974. The influence of subalpine snowbanks on vegetation pattern, production and phenology. Bulletin of the Torrey Botanical Club, vol. 101, no. 6, pp. 340-350.

CelińSkI F., WojterSkI T., 1962. Mapa zbiorowisk roślinnych Babiogórskiego Parku Narodowego w 1960. Poznań: Poznańskie Towarzystwo Przyjaciół Nauk.

Celinśsi F., Wojterski T., 1963. Świat roślinny Babiej Góry [in:] W. Szafer (ed.), Babiogórski Park Narodowy, Kraków: Zakład Ochrony Przyrody PAN, Państwowe Wydawnictwo Naukowe, pp. 109-170.

\section{Acknowledgements}

The Authors would like to thank the Babiogórski National Park for access to the Airborne Laser Scanning data. The authors also wish to thank Dr. Małgorzata Błaszczyk for performing the orthorectification procedure.

The work was conducted as part of the research project of the Polish National Science Centre NN 306 070640, entitled Natural and anthropogenic conditioning of the occurrence of the timberline on Babia Góra Mountain, and its dynamics over the last 200 years.

Editors' note:

Unless otherwise stated, the sources of tables and figures are the authors' on the basis of their own research.

CIURZYCKI W., 2004. Struktura przestrzenna naturalnych odnowień świerkowych na górnoreglowych polanach popasterskich w Tatrach Polskich. Sylwan, 7, pp. 20-30.

CZAJKA B., 2012. Wpływ wysokości n.p.m. na wrazliwość klimatycznq świerka pospolitego w masywie Babiej Góry. Studia i Materiały Centrum Edukacji Przyrodniczo-Leśnej, vol. 1, no. 30, pp. 91-97.

CZAJKa B., KaCZKa R.J., ŁaucZAK A., 2015a. Timberline in the Carpathians: An overview. Geographia Polonica, vol. 88, no. 2, pp. 7-34.

CZAJKa B., KaCZKa R.J., ŁaucZak A., 2015b. Geographical characteristics of the timberline in the Carpathians. Geographia Polonica, vol. 88, no. 2, pp. 35-54.

DŁugosz M., 2012, Digital terrain model (DTM) as a tool for landslide investigation in the Polish Carpathians. Studia Geomorphologica Carpatho-Balcanica, vol. 46, pp. 5-23.

Fensham R.J., Falrfax R.J., 2002. Aerial photography for assessing vegetation change: a review of applications and the relevance of findings for Australian vegetation history. Australian Journal of Botany, vol. 50, no. 4, pp. 415-429.

Griffiths P., Kuemmerle T., Baumann M., Radeloff V.C., Abrudan I.V., LIESKOVSKY J., Munteanu C., Ostapowicz K., Hostert P., 2014. Forest disturbances, forest recovery, and changes in forest 
types across the Carpathian ecoregion from 1985 to 2010 based on Landsat image composites. Remote Sensing of Environment, vol. 151, pp. 72-88.

GuzIK M., 2008. Analiza wpływu czynników naturalnych i antropogenicznych na kształtowanie się zasięgu lasu i kosodrzewiny w Tatrach. Kraków: Uniwersytet Rolniczy im. Hugona Kołłąaja. Wydział Leśny. Katedra Botaniki Leśnej i Ochrony Przyrody [PhD thesis].

Hatat P., 2006. Wpływ asymetrii masywu Babiej Góry na piętrowość fizycznogeograficzna. Ochrona Beskidów Zachodnich, 1, pp. 81-91.

Harsch M.A., Hulme P.E., Mcglone M.S., DunCAN R.P., 2009. Are treelines advancing? A global meta-analysis of treeline response to climate warming. Ecology Letters, vol. 12, no. 10, pp. 1040-1049.

HolekSA J., 1998. Rozpad drzewostanu i odnowienie świerka a struktura i dynamika karpackiego boru górnoreglowego. Monographia Botanicae, 82, Łódź-Warszawa: Polskie Towarzystwo Botaniczne.

Holtmeler F.H., 2009. Mountain Timberlines: Ecology, patchiness, and dynamics. Advances in Global Change Research, 36, Dordrecht: Springer.

IPCC, 2013. Climate change 2013: The physical science basis. Contribution of Working Group I to the Fifth Assessment Report of thelntergovernmental Panel on Climate Change. Cambridge-New York: Cambridge University Press.

JeNNESS J., 2006. Topographic Position Index (TPI) v. 1.2. Flagstaff, AZ: Jenness Enterprises, http:// www.jennessent.com/arcview/tpi.htm [5 March 2015].

Jostowa W., 1972. Pasterstwo na polskiej Orawie. Wrocław-Warszawa-Kraków-Gdańsk: Zakład Narodowy im. Ossolińskich, Wydawnictwo PAN.

KACZKA R.J., CZAJKA B., ŁAJCZAK A., 2015. The tree-ring growth responses to climate in the timberline ecotone of Babia Góra Mountain. Geographia Polonica, vol. 88, no. 2, pp. 163-176.

Kasprzak M., TraczyK A., 2010. Geomorfometria granitowej części Karkonoszy. Landform Analysis, 13, pp. 33-46.

Kasprowicz M., 1996. Zróżnicowanie i przekształcenia roślinności pięter reglowych masywu Babiej Góry (Karpaty Zachodnie). Idee Ekologiczne, vol. 9, no. 3, pp. 1-214.

KONDRACKI J., 1978. Karpaty. Warszawa: Wydawnictwa Szkolne i Pedagogiczne.

KOZAK J., 2003. Forest cover change in the Western Carpathians in the past 180 years. A Case study in the Orawa Region in Poland. Mountain Research and Development 23, pp. 369-376.

KÖRNER Ch., 2003. Limitation and stress - always or never? Journal of Vegetation Sciences, vol. 14, no. 2, pp. 141-143.

KöRNER Ch., 2012. Alpine treelines: Functional ecology of the global high elevation tree limits. Basel: Springer.

Kricsfalusy V., Mróz W., Popov S., 2008. Historical changes of the upper tree line in the Carpathian Mountains (Ukraine). Mountain Forum Bulletin, http://www.mtnforum.org/sites/default/files/ publication/files/1087.pdf. [5 January 2015]

KSIAŻKIEWICZ M., 1966. Geologia regionu babiogórskiego. Przewodnik, 39, pp. 2-5.

KSIAŻKIEWICZ M., 1968. Szczegółowa mapa geologiczna Polski 1: 50,000. Sheet M34-88a-Zawoja.

KucharzYK S., AugustYn M., 2008. Dynamika górnej granicy lasu w Bieszczadach Zachodnich zmiany w ciagu póttora wieku. Studia Naturae, vol. 54, no. 2, pp. 133-156.

KULLMAN L., 2001. 20th century climate warming and the tree-limit rise in the southern Scandes of Sweden. Ambio: A journal of the Human Environment, vol. 30, no. 2, pp. 72-80.

LuO G., Dol I., 2013. Detection of alpine tree line change with high spatial resolution remotely sensed data. Journal of Applied Remote Sensing, vol. 7, no. 1, 073520-073520.

ŁAJCZAK A., 1998. Charakterystyka geomorfologiczna i wykonanie szczegótowej mapy geomorfologicznej Babiogórskiego Parku Narodowego. Plan Ochrony Babiogórskiego Parku Narodowego, Kraków-Zawoja [manuscript].

ŁAUCZAK A., 1999. Charakterystyka hydrograficzna, zasoby wodne i wykonanie szczegółowej mapy hydrograficznej Babiogórskiego Parku Narodowego. Plan Ochrony Babiogórskiego Parku Narodowego, Kraków-Zawoja [manuscript].

MaCiAs-Fauria M., Johnson A.E., 2013. Warminginduced upslope advance of subalpine forest is severely limited by geomorphic processes. Proceedings of the National Academy of Sciences, vol. 110, no. 20, pp. 8117-8122.

Migoń P., PARZÓCH K., 2008. Debris flows in the (Polish) Karkonosze Mountains-causes, effects and associated hazards. Przegląd Geograficzny, vol. 80, no. 3, pp. 385-401.

Mihal B., SavulesCu I., Sandric I., 2007. Change detection analysis (1986-2002) of vegetation cover 
in Romania. A Study of alpine, subalpine, and forest landscapes in the lezer Mountains, Southern Carpathians. Mountain Research and Development, vol. 27, no. 3, pp. 250-258.

NASSET E., 1997. Determination of mean tree height of forest stands using airborne laser scanner data. ISPRS Journal of Photogrammetry and Remote Sensing, vol. 52, no. 2, 49-56.

NeSSET E., ØKLAND T., 2002. Estimating tree height and tree crown properties using airborne scanning laser in a boreal nature reserve. Remote Sensing of Environment, vol. 79, no. 1, pp. 105-115.

OBIDOwICZ A., 1996. Polodowcowa historia szaty roślinnej [in:] Z. Mirek (ed.), Przyroda Tatrzańskiego Parku Narodowego. Kraków-Zakopane: Tatrzański Park Narodowy, pp. 229-236.

Obidowicz A., 2003. The Holocen development of forests in the Pilsko Mt. Area (Beskid Żywiecki Range, South Poland). Fola Quaternaria, 74, pp. 7-15.

OBIDOWICZ A., 2004. Holoceńska historia roślinności Babiej Góry. [in:] B.W. Wołoszyn, A. Jaworski, J. Szwagrzyk (eds.), Babiogórski Park Narodowy: Monografia Przyrodnicza, Kraków: Wydawnictwo i Drukarnia Towarzystwa Słowaków w Polsce, pp. 423-428.

ObręsSkA- Starklowa B., 1963. Klimat Babiej Góry [in:] W. Szafer (ed.), Babiogórski Park Narodowy, Kraków: Zakład Ochrony Przyrody PAN, Państwowe Wydawnictwo Naukowe, pp. 45-67.

OMYLAK J., 2005. Z dziejów poznania i Ochrony [in:] D. Ptaszycka-Jackowska (ed.), Światy Babiej Góry, Wadowice: Grafikon, pp. 147-168.

Parzóch K., Migoń P., SzYManowski R., 2008. Wspótczesne procesy geomorfologiczne w ekotonie górnej granicy lasu w Karkonoszach Polskich [in:] A. Mazur, A. Raj, R. Knapik (eds.), Monitoring ekosystemów leśnych w Karkonoskim Parku Narodowym, Jelenia Góra: Karkonoski Park Narodowy, pp. 39-55.

Paulsen J., Weber U.M., Körner Ch., 2000. Tree growth near treeline: Abrupt or gradual reduction with altitude. Arctic Antarctic and Alpine Research, vol. 32, no. 1, pp. 14-20

Pike R.J., Evans I.S., Hengl T., 2008. Geomorphometry: A brief guide. [in:] T. Hengl, H.I. Reuter (eds.), Geomorphometry: Concepts, software, applications. Developments in Soil Science, vol. 33, pp. 3-30.
Plesník P., 1971. Horná hranica lesa vo Vysokých a Belanských Tatrách. Bratislava: Vydavatelstvo Slovenskej Akadémie Vied.

Razak K.A., Straatsma M.W., van Westen C.J., MaLet J.P., DE JONG S.S., 2011. Airborne laser scanning of forested landslides characterization: Terrain model quality and visualization. Geomorphology, vol. 126, no. 1-2, pp. 186-200.

SitKo I., Troll M., 2008. Timberline Changes in relation to summer farming in the Western Chornohora (Ukrainian Carpathians). Mountain Research and Development vol. 28, no. 3-4, pp. 263-271.

SoKOŁOWSKI M., 1928, O górnej granicy lasu w Tatrach. Kraków: Zakłady Kórnickie.

Strand E.K., Smith A.M., Bunting S.C., Vierling L.A., HannD.B., Gessler P.E., 2006. Wavelet estimation of plant spatial patterns in multitemporal aerial photography. International Journal of Remote Sensing, vol. 27, no. 10, pp. 2049-2054.

SZWAgrZYK J., SZEWCZYK J., BodZIARCZYK J., 1995. Structure of forest stand in the Zarnowka Reserve of the Babia Gora National Park. Folia Forestalia Polonica. Series A. Forestry, 37, pp. 111-123

SzWagrzyk J., SzewczYK J., Kaczor K., 1996. Relationship between stand structure and advanced forest regeneration in an old-growth stand of $B a-$ bia Góra National Park. Ekologia Polska, vol. 44, no. 1-2, pp. 137-151.

Topographic map 1:10,000, 1983. Arkusz Przywarówka Zubrzyca Górna i Zawoja. Państwowy Układ Współrzędnych 1965.

Treml V., Banaš M., 2000. Alpine timberline in the High Sudetes. Acta Universitatis Carolinae, vol. 35, no. 2, pp. 83-99.

TREML V., 2007. The effect of terrain morphology and geomorphic processes on the position and dynamics of the alpine timberline. A case study from the High Sudetes, Czech Republic [in:] A.S. Goudie, J. Kalvoda (eds.), Geomorphological Variations, Prague: P3K, pp. 298-312.

TRANQUILLINI W., 1979. Physiological ecology of the alpine timberline - tree existence at high altitudes with special reference to the European Alps. Ecological Studies, 31, Berlin: Springer.

TROLL C., 1973. The upper timberlines in different climatic zones. Arctic and Alpine Reserche, vol. 5, no. 3, pp. 3-18.

VorČ́́K J., JANKOVIČ J., 2009. Autovegetatívna obnova smreka na hornej hranici supramontánneho 
stupňa a v subalpínskom stupni Babej Hory a Pilska v Oravských Beskydách. Lesnícky Časopis, vol. 55, no. 1, pp. 29-46.

Westen van C.J., Getahun J.F., 2003. Analyzing the evolution of the Tessina landslide using aerial photographs and digital elevation models. Geomorphology, vol. 54, no. 1, pp. 77-89.

Weż̀Y P., Borowiec N., Szombara S., Wańczyk R., 2008. Generation of digital surface and terrain models of the Tatras mountains based on Airbone Laser Scanning (ALS) point cloud. Archiwum Fotogrametrii, Kartografii i Teledetekcji, 18, pp. 651-661.

Weisberg P.J., Shandra O., Becker M.E., 2013. Landscape influences on recent timberline shifts in the Carpathian Mountains: Abiotic influences modulate effects of land-use change. Arctic, Antarctic and Alpine Research, vol. 45, no. 3, pp. 404-414.

Wieser G., TAusz M. (eds.), 2007. Trees at their upper limit: Treelife limitation at the alpine timberline. Kluwer Handbook Series of Plant Ecophysiology, 5, Dordrecht: Springer.

Williams N.W., losleben M., Caine N. GreenLAND D., 1996. Change in climate and hydro- chemical responses in a high-elevation catchment in the Rocky Mountains, USA. Limnological Oceanography, vol. 41, no. 5, pp. 939-946.

Wooldridge G.L., Musselman R.C., Sommerfeld R.A., Fox D.G., Connel B.H., 1996. Mean wind patterns and snow depths in an alpinesubalpine ecosystem as measured by damage to conifers. Journal of Applied Ecology, 33, pp. 100-108.

Zapałowicz H., 1879. Roślinność Babiej Góry pod względem geograficzno-botanicznym. Sprawozdanie Komisyi Fizjograficznej. Materiały do fizjografii Galicji, 14, pp. 79-250.

ZARZYCKI K., 1963. Lasy Bieszczadów Zachodnich. Acta Agraria et Silvestra, 3, pp. 1-132.

ZIENTARSKI J., 1985. Wpływ wzniesienia oraz wielkości masywu górskiego na kształtowanie się górnej granicy lasu w Polsce. Poznań: Akademia Rolnicza [PhD thesis].

ZięTARA T., 1989. Rozwój teras krioplanacyjnych w obrębie wierzchowiny Babiej Góry w Beskidzie Wysokim. Folia Geographica. Seria Geographica-Physica, 21, pp. 81-92. 